\title{
INVESTIGATION OF BATRACHOCHYTRIUM DENDROBATIDIS IN FOUR BOREAL TOAD (BUFO BOREAS BOREAS) POPULATIONS IN WYOMING
}

\author{
Sophie St-Hilaire, Sarah Bruner, Peter Murphy, Debra Patla And \\ CHARles PETERSON $\downarrow$ DEPARTMENT OF BIOLOGICAL SCIENCES \\ IDAHO STATE UNIVERSITY \ POCATELLO
}

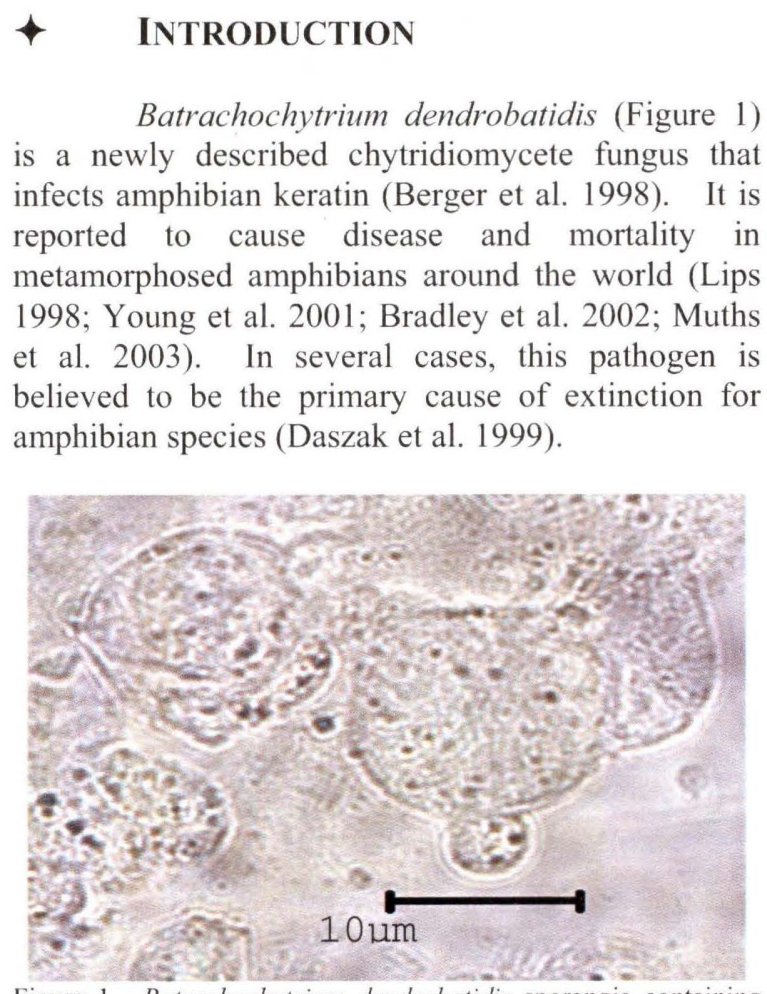

Figure 1. Batrachochytrium dendrobatidis sporangia containing zoospores (400x).

Within the last few years, the United States Geological Survey (USGS), in conjunction with Idaho State University (ISU) and the National Park
Service, has been screening amphibian populations for $B$. dendrobatidis in the Rocky Mountain area. Boreal toads (Bufo boreas boreas) (Figure 2), once common in Colorado, have likely been decimated by chytridiomycosis (disease associated with $B$. dendrobatidis) (Muths et al. 2003). In a recent study by Carey et al. (2006) the boreal toad from Colorado was found to be susceptible to the $B$. dendrobatidis under laboratory conditions.

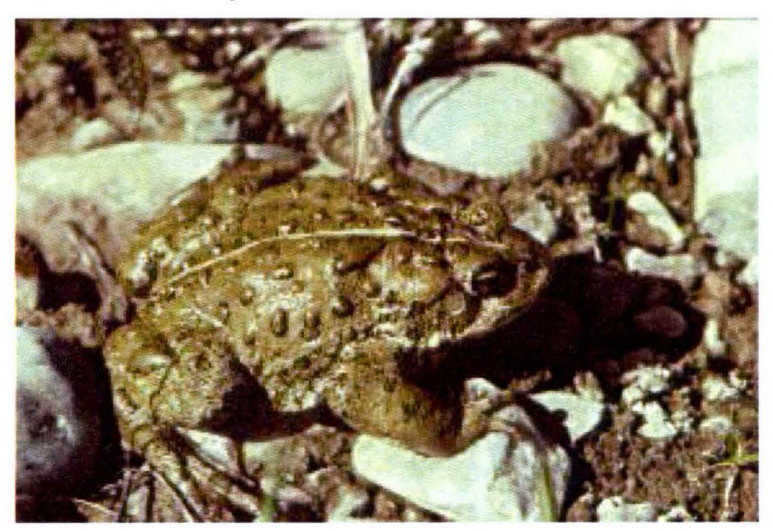

Figure 2. Boreal toad, Bufo boreas boreas

On the other hand, $B$. dendrobatidis has been identified in at least 4 populations of boreal toads in Grand Teton National Park (Figure 3) and the adjacent Bridger-Teton National Forest (Erin Muths and Susan Wolff, personal communication) and 2 populations in the adjacent National Elk 
Refuge (D. Patla, personal communication), yet significant mortality has not been reported. Repeated sampling of tagged boreal toads by USGS suggests animals can survive from one year to the next with the fungus (E.Muths, personal communication). Similar variation in the mortality rates associated with this fungus has been reported in other parts of the world (Berger et al 1998; Retallick et al 2004). These findings have given rise to a number of questions regarding the host, pathogen and environmental factors involved in the manifestation of chytridiomycosis.

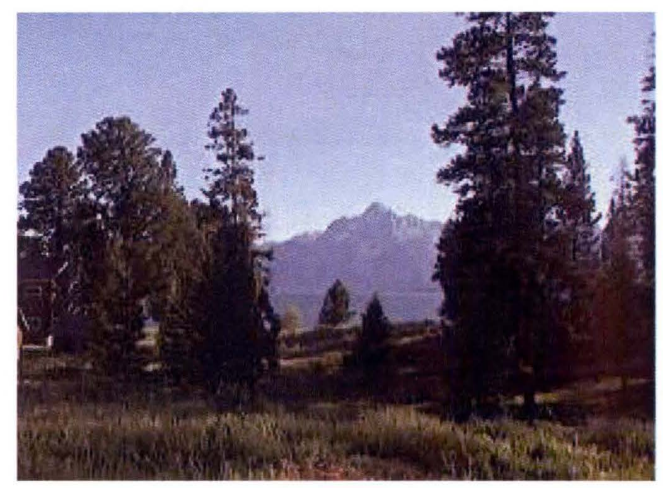

Figure 3. Grand Teton National Park

More information on the spatial and temporal distribution of this potential pathogen within the Greater Yellowstone Ecosystem, and the factors necessary to induce chytridiomycosis is required. The breeding sites in the greater Grand Teton area provide a unique opportunity to study this fungal pathogen in a region where it does not appear to cause significant acute disease in amphibians.

\section{$\downarrow$ MeTHODS}

We sampled different life stages of boreal toads at four sites where $B$. dendrobatidis has been detected in recent years on the skin of adult amphibians. These data provide additional information on the infection status of populations sampled in previous years. In addition, the data provide information on the life stage(s) when toads become infected with the pathogen. Data were collected in collaboration with members of the USGS amphibian monitoring program (Erin Muths and Steve Corn), and the Grand Teton National Park biologist (Susan Wolff). The sampling scheme used also provided us with the opportunity to culture of $B$. dendrobatidis isolates for our laboratory-based pathogenicity studies.
Four boreal toad breeding sites (Blackrock area oxbow pond on the Bridger-Teton National Forest, Snake River Quarry near Flagg Ranch in the J.D. Rockeller Memorial Parkway of GTNP, Nowlin Creek on the National Elk Refuge, and Lower Schwabacker in GTNP) within a 60 mile radius of the UW-NPS Research Station were visited (Figure 4). Different life stages of amphibians were collected and tested for $B$. dendrobatidis using PCR techniques and culture as described in Annis et al (2004) and Rachowicz and Vredenburg (2004), respectively.

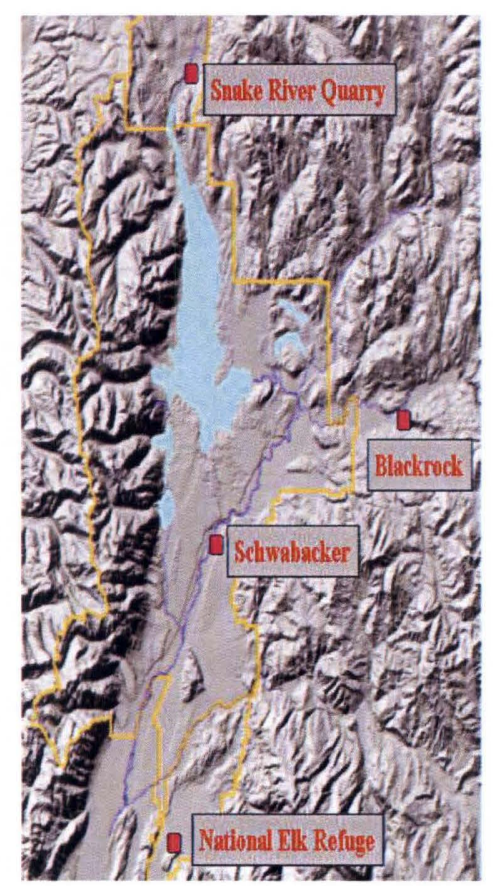

Figure 4. Study sites in relation to Grand Teton National Park

Approximately twenty metamorphs (toadlets) from each of the sites (except Schwabacker where no metamorphs were found) were also swabbed in a similar manner as the adult toads with the exception that cotton swabs were used for both the fungal culture sample and the PCR sample.

Approximately twenty adults were nonlethally sampled during the breeding season at each of the locations. Adults were also tested whenever they were found on subsequent visits. Animals were swabbed twice, once with a sterile plastic bioloop (Fisher cat \# 13-075-3) and a second time with a cotton tipped wooden applicator stick (Fisher cat \# 14-959-91) (Figure 5). The plastic loop was stored in ethanol and the cotton swab was stored in TGhL culture broth (Johnson, Amphibian Diseases Ecology Group, School of Public Health and tropical Medicine, Townsville, Australia). 
Up to 6 strands of eggs $(5 \mathrm{~cm}$ in length) at each of the four study sites, with the exception of the Snake River Quarry where no eggs were found, were collected in ethanol for PCR testing. Between 20 and 40 tadpoles were euthanized in Tricaine methane sulfonate (MS-222), examined for mouthpart abnormalities at 10X magnification, and stored in ethanol for subsequent testing by PCR.

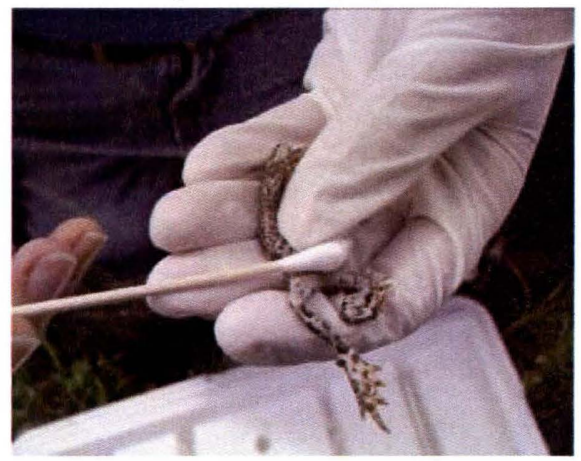

Figure 5. Bufo boreas boreas being swabbed ventrally for chytrid

Adult $^{1}$ and metamorph PCR samples were tested at Idaho State University. Tadpoles and eggs were sent to Pisces Molecular laboratory (Boulder, Colorado) for evaluation. For tadpoles, only the mouthparts were submitted for testing as only these parts contain keratinized tissue necessary for chytrid growth (Longcore et al. 1999). Mouthparts were pooled into groups of three to five animals from similar locations. An attempt was also made to only submit the outer layer of the egg membrane for PCR testing to avoid dilution of the samples.

\section{Chytrid PCR Protocol (ISU)}

Swabs in ethanol were vortexed and all liquid was decanted into a centrifuge tube. Samples with plastic loops were centrifuged directly. Tubes were spun at 13000 RPM for 10 minutes in a microcentrifuge. The ethanol was then decanted and discarded, while the sample tubes with pellet were dried at $37^{\circ} \mathrm{C}$ for approximately 30 minutes, or until all ethanol had evaporated. Pellets were then resuspended in $25 \mu \mathrm{l}$ of sterile-filtered TRIS. This was used directly in the PCR reaction.

Each PCR reaction consisted of $50-\mu$ l total volume in a $0.2 \mathrm{~mL}$ thin-walled PCR tube. Each reaction consisted of $5 \mu \mathrm{l}$ of $10 \mathrm{x}$ buffer, $29.5 \mu \mathrm{l}$ of nuclease-free water, $8 \mu \mathrm{l}$ of dNTPs (di-

\footnotetext{
${ }^{1}$ The 4 adult toads sampled from the National Elk Refuge were sent to Pisces Molecular Laboratory for PCR testing.
}

nucleotriphosphates), $1 \mu \mathrm{l}$ of forward primer Bdla, 1 $\mu 1$ of reverse primer Bd2a, $0.5 \mu 1$ of Polymerase and 5 $\mu \mathrm{l}$ of sample template. The PCR primers used in this study are described in Annis et al. (2004). Primer Bdla was

5'-CAGTGTGCCATATGTCACG-3' and $\mathrm{Bd} 2 \mathrm{a}$ was

5'-CATGGTTCATATCTGTCCAG-3' ; both were made by Integrated DNA Technologies.

PCR reaction tubes were placed in a thermocycler and were run on the following program: 10 minutes at $95{ }^{\circ} \mathrm{C}$ to lyse cells, 40 cycles of 1 minute at $95^{\circ} \mathrm{C}, 1$ minute at $60{ }^{\circ} \mathrm{C}$ (annealing) and 1 minute at $72{ }^{\circ} \mathrm{C}$ (elongation), followed by a final elongation of 4 minutes at $72^{\circ} \mathrm{C}$. Samples were then stored at $4{ }^{\circ} \mathrm{C}$.

For each PCR product, $5 \mu \mathrm{l}$ was added to 1 $\mu \mathrm{l}$ of $6 \mathrm{x}$ bromophenyl blue loading dye and loaded into a $1 \%$ agarose gel stained with Ethidium Bromide. The gel was run in an electrophoresis block at $98 \mathrm{~V}$ constant for approximately 25 minutes, then removed. Gels were viewed using a photo imager using the program "Flour-S". A fluorescent band at 300 base-pairs indicated a positive PCR reaction for the primers used in this study. Bands from a select number of positive samples were sequenced to confirm the product.

\section{Culture}

Broth and agar media containing Tryptone, hydrolysed gelatine, lactose, and the antibiotics streptomycin, tetracycline and Penicillin G were made as described by Johnson (http://www.jcu.au/school/phtm/PHTM/frogs/protoco 1/bd-media-protocol.pdf). Subsequent media for the toadlet swab samples was made using Fluconozole (an anti-yeast agent).

Swabs were inoculated in the TGhL broth at least overnight and up to 3 days at approximately $18^{0}$ C. These were subsequently plated on TGhL agar plates and placed at $18{ }^{\circ} \mathrm{C}$ for 7 days. The plates were examined for growth every other day. Colonies were examined under 1000X light microscopy. Plates with excessive growth were sub-sampled, and later examined for identification of organism(s). Gram stains were done on approximately 30 smears. 


\section{RESULTS}

PCR

Batrachochytrium dendrobatidis was detected by PCR and confirmed by sequencing on adults during the breeding season at all four study sites sampled in 2005 (Table 1). With the exception of the National Elk Refuge, the prevalence of $B$. dendrobatidis was relatively low (range between $2.8 \%$ and $25 \%$ ). Only 4 adults were sampled from the National Elk Refuge during the breeding season, but 2 of these were PCR positive for $B$. dendrobatidis. The only metamorph that tested positive by PCR was also from the National Elk Refuge (Table 1).

\begin{tabular}{|c|c|c|}
\hline & Number tested & $\begin{array}{l}\text { Number } \\
\text { positive }\end{array}$ \\
\hline \multicolumn{3}{|l|}{ Blackrock } \\
\hline $\begin{array}{l}\text { Adults during breeding } \\
\text { season }\end{array}$ & 36 & $1(2.8 \%)$ \\
\hline Adults during summer & 5 & $2(40 \%)^{2}$ \\
\hline Eggs & 5 strands & 0 \\
\hline Tadpoles & $\begin{array}{c}9 \text { samples }(36 \\
\left.\text { tadpoles }^{1}\right)\end{array}$ & 0 \\
\hline Metamorphs & 21 & 0 \\
\hline \multicolumn{3}{|l|}{ Schwabacker } \\
\hline $\begin{array}{l}\text { Adults during breeding } \\
\text { season }\end{array}$ & 19 & $1(5.3 \%)$ \\
\hline Adults during summer & 10 & 0 \\
\hline Eggs & 1 strand & 0 \\
\hline Tadpoles & $\begin{array}{c}7 \text { samples ( } 20 \\
\text { tadpoles) }\end{array}$ & 0 \\
\hline Metamorphs & 1 & 0 \\
\hline \multicolumn{3}{|l|}{$\begin{array}{l}\text { National } \\
\text { (Nowlin) }\end{array}$ Elk Refuge } \\
\hline $\begin{array}{l}\text { Adults during breeding } \\
\text { season }\end{array}$ & 4 & $2 *(50 \%)$ \\
\hline Adults during summer & 11 & 0 \\
\hline Eggs & 5 strands & 0 \\
\hline Tadpoles & $\begin{array}{l}4 \text { samples ( } 8 \\
\text { tadpoles) }\end{array}$ & 0 \\
\hline Metamorphs & 32 & 1 \\
\hline \multicolumn{3}{|l|}{ Snake River Quarry } \\
\hline $\begin{array}{l}\text { Adults during breeding } \\
\text { season }\end{array}$ & 20 & $5(25 \%)$ \\
\hline Adults during summer & 0 & $\mathrm{NA}$ \\
\hline Eggs & 0 & NA \\
\hline Tadpoles & $\begin{array}{c}6 \text { samples }(28 \\
\text { tadpoles })\end{array}$ & 0 \\
\hline Metamorphs & 20 & 0 \\
\hline
\end{tabular}

Table 1. Summary of test results for animal sampled for Batrachochytrium dendrobatidis. Included are the location where the animal was sampled and its life stage.

*Pisces lab

${ }^{1}$ Two tadpoles had missing pigment on their mouth parts.

${ }^{2}$ One of these samples was abnormally shedding skin.
None of the tadpoles sampled or any of the egg samples were positive for $B$. dendrobatidis by PCR (Table 1).

\section{Culture}

No samples cultured positive for $B$. dendrobatidis. Many of the cultures were overgrown by yeast within 3 days. Samples cultured on TGhL agar plates containing fluconozole were negative for $B$. dendrobatidis by PCR and culture. These had limited yeast growth.

\section{DiscuSsion}

Batrachochytrium dendrobatidis was identified by PCR in breeding adult boreal toads from each of the four locations sampled, which is consistent with previous studies conducted in these areas. However, with the exception of the adult toads sampled from the National Elk Refuge, which were tested at a different laboratory, the prevalence of the fungus in populations sampled in this study was generally lower than in previous years. The discrepancy in prevalence between sites and between years may be attributed to the different laboratories (and technique) used for PCR testing.

No mortalities were noted at any of the sites visited and all toads sampled, with the exception of one which was abnormally shedding its skin, appeared normal. The individual with clinical signs of chytridiomycosis (abnormally shedding its skin) tested positive for $B$. dendrobatidis by PCR (Table $1)$.

Based on these results it would appear that B. dendrobatidis is still present in the Grand Teton National Park area, and toads with the fungus generally do not have clinical signs of chytridiomycosis.

We did not detect the fungus on any eggs or tadpoles, and these findings were consistent with other reports that these life stages of the boreal toad are not susceptible to the fungus. However, a recent report by Blaustein et al. (2005) suggests tadpoles may be susceptible to disease when exposed to $B$. dendrobatidis experimentally. Based on the data in our study it would appear that toads are likely becoming infected with the pathogen as adults, and perhaps occasionally as metamorphs (toadlets). 
Batrachochytrium dendrobatidis was not confirmed by culture in any of the samples collected $(\mathrm{n} \cong 150)$. In many cases, yeast was apparent on the cultures within 3 days. Whether or not this prohibited $B$. dendrobatidis from growing is unknown. Fluconozole was added to the culture media for the samples collected from the toadlets and the adults sampled late in the summer to suppress yeast; however, these individuals (with the exception of 1) were negative for the fungus by PCR so the media could not be properly assessed on field samples. Using an established laboratory culture Fluconozole appears to suppress $B$. dendrobatidis slightly.

\section{$\downarrow$ FUTURE RESEARCH}

More research is required on the role water quality parameters play in the manifestation of chytridiomycosis. The $\mathrm{pH}$ of water at the sites sampled last year was above 8.0 and the conductivity was greater than $140 \mu$ s (Table 2). These water quality parameters may not be conducive for $B$. dendrobatidis growth and may explain why it is not causing acute disease in toads found at the four sites sampled.

\begin{tabular}{|l|l|l|l|l|}
\hline Location & $\begin{array}{l}\text { UTM } \\
(\mathrm{Nad} 27 \\
\mathrm{z} 12)\end{array}$ & $\mathrm{pH}$ & $\begin{array}{l}\text { Conductivity } \\
(\mu \mathrm{s})\end{array}$ & $\begin{array}{l}\text { Temperatur } \\
\mathrm{e}(\mathrm{C})\end{array}$ \\
\hline Blackrock & $\begin{array}{l}552480, \\
4853370\end{array}$ & 9.8 & 176.4 & 18 \\
\hline Schwabacker & $\begin{array}{l}526473, \\
4839952\end{array}$ & 8.4 & 161.7 & 16 \\
\hline $\begin{array}{l}\text { National Elk } \\
\text { Refuge }\end{array}$ & $\begin{array}{l}522372, \\
4818872\end{array}$ & 9.0 & 300 & 30 \\
\hline $\begin{array}{l}\text { Snake River } \\
\text { Quarry }\end{array}$ & $\begin{array}{l}525406, \\
4881761\end{array}$ & 9.58 & 139.5 & 24 \\
\hline
\end{tabular}

Table 2. Location of sites where toads were sampled and water quality parameters at the sites. Water quality was taken the first week of August 2005.

In a study by Hawk (2000) it was found that the boreal toad populations with the best breeding success in the Greater Yellowstone area were those using ponds with high conductivity water. It was hypothesized that this water parameter reduced osmoregulatory stress (Hawk, 2000).

In the summer of 2006, we will investigate the role of water quality parameters on the development of chytridiomycosis by sampling more sites for $B$. dendrobatidis and collecting detailed water quality information, including temperature, conductivity and $\mathrm{pH}$, over time at each location, and by conducting laboratory challenges using different water conductivity and $\mathrm{pH}$. Our laboratory study will also permit us to evaluate the susceptibility of the boreal toad found in Wyoming to $B$. dendrobatidis. Furthermore, we will modify our culture media and attempt to culture the fungus again in 2006 on animals that are likely to be infected (i.e. breeding adults).

\section{- Literature Cited}

Annis, S.L., F.P. Dastoor, H. Ziel, P. Daszak and J.E. Longcore. 2004. A DNA-based assay identifies Batrachochytrium dendrobatidis in amphibians. Journal of Wildlife Diseases 40(3):420-428.

Berger, L., R. Speare, P. Daszak, D.E. Green, A.A. Cunningham, C.L. Goggin, R. Slocombe, M.A. Ragan. 1998. . Chytridiomycosis causes amphibian mortality associated with population declines in the rain forests of Australia and Central America. Proceedings of the National Academy of Sciences of the United States of America 95, pp. 90319036, July 1998.

Bradley, G.A., P.C. Rosen, M.J. Sredl, T.R. Jones, and J.E. Longcore. 2002. Chytridiomycosis in native Arizona frogs. Journal of Wildlife Diseases 38: 206-212.

Carey, C., J.E. Bruzgul, L.J. Livo, M.L. Walling, K.A. Kuehl, B.F. Dixon, A.P. Pessier, R.A. Alford and K.B. Rogers. 2006. Experimental exposures of boreal toads (Bufo boreas) to a pathogenic chytrid fungus (Batrachochytrium dendrobatidis). EcoHealth (In press).

Daszak, P., L. Berger, A.A. Cunningham, A.D. Hyatt, D.E. Green, and R. Speare. 1999. Emerging infectious diseases and amphibian population declines. Emerging Infectious Diseases 5: 735-748.

Hawk, J.E. 2000. Amphibian declines in the Greater Yellowstone Ecosystem: do thermally influenced waters protect boreal toads from bacterial disease? MS Thesis, Idaho State University.

Hyatt, D., K.R. McDonald, H.B. Hines, K.R. Lips, G. Marantelli, and H. Parkes. 1998. Chytridiomycosis causes amphibian mortality associated with population declines in the rain forests of Australia and Central America. Proceedings of the 
National Academy of Sciences of the United States of America 95: 9031-9036.

Johnson, M.L. and R. Speare. 2003. Survival of Batrachochytrium dendrobatidis in water: Quarantine and disease control implications. Emerging Infectious Diseases 9: 922-925.

Lips, L.R. 1998. Decline of a tropical montane amphibian fauna. Conservation Biology 12: 106-117.

Longcore, J.E., A.P. Pessier and D.K. Nichols.1999. Batrachochytrium dendrobatidis gen. et sp. nov., a chytrid pathogenic to amphibians. Mycologia 91(2): 219-227.

Muths, E., P.S. Corn, A.P. Pessier, and D.E. Green. 2003. Evidence for disease-related amphibian decline in Colorado. Biological Conservation 110: 357-365.

Rachowicz, L. and V. Vredenburg. 2004. Transmission of Batrachochytrium dendrobatidis within and between amphibian life stages. Diseases of Aquatic Organisms 61: 75-83.
Retallick, R.W.R., H. McCallum and R. Speare. 2004. 'Endemic infection of the amphibian chytrid fungus in a frog community postdecline.' PLoS Biology, 2(11).

Young, B.E., K.R. Lips, J.K. Reaser, R. Ibanez, A. W. Salas, J.R. Cedeno, L.A. Coloma, S. Ron, E. La Marca, J.R. Meyer, A. Munoz, F. Bolanos, G. Chaves and D. Romo. 2001. Population declines and priorities for amphibian conservation in Latin America. Conservation Biology 15: 1213-1223. 